somewhat in their spectroscopic properties. It may be found that the same statement is true of the visual pigments. If these pigments resemble hæmoglobin in having protein prosthetic groups, it may be differences in the latter which bring about the changes in wave-lengths.

Here then are data obtained several years ago, by two methods on animals' retinas ${ }^{2}$ and by two methods on humans' retinas ${ }^{3}$, which are in agreement, within experimental error, with this modern scheme suggested by Dartnall of an equal frequency difference series. That this could not possibly happen by chance is quickly proved by applying the same criterion to random wave-lengths, because when this is done no agreement is found to occur (see Fig. 4). When, therefore, Collins and Morton write "It follows that the evidence for a constant frequency difference is quite inadequate", the weight of evidence seems to be definitely against their view.

Now, if the facts presented in this and previous communications were the only evidence available, it would still appear to be sufficient to substantiate all the above statements ; but, in fact, three additional pieces of evidence are available which have not so far been mentioned.

(a) It is possible in other ways to determine approximately the crest wave-lengths of the human receptors. Moreover, these wave-lengths are found to be in good agreement (1) with those quoted above which are given by the fixation point and the sub. jective colour methods, (2) with those found in animals, (3) with the retinal pigments as determined by Dartnall, and (4) with the constant frequency difference series.

(b) The shapes of the response curves both of human and of animal receptors resemble one another in being single hump curves. They also resemble the wave-length - optical density curves of the retinal pigments in the same respect.

(c) The spans (half-height widths) of the response curves both of human and of animal receptors do not differ much from one another. Nor do they differ much from the spans of the wave-length-optical density curves of the retinal pigments. It seems likely that further research will demonstrate conformity between the spans of the receptors of different wave-length and of the corresponding pigments.

Several other physiological points might be raised with regard to Collins and Morton's letter, but three only will be referred to here.

(1) They write, "As cattle are believed to have only rods in their retinas . . .". This belief is not supported by Sir Herbert Parsons in his book on "Colour Vision"4. He writes: "Greeff" says that there are rods and cones in the retinæ of most mammals,... There are vertebrates possessing only rods ... amongst mammals, hedgehog, bat, mole and nightape ...". Thus cattle would have both rods and cones.

(2) Later on, Collins and Morton write : "as Hartridge mixes up eyes using vitamin $A_{1}$ and vitamin $A_{2}$. . .". They are presumably referring to the fact that Dartnall worked on tench, whereas Granit worked on various animals - cats, rats, guinea pigs, snakes, frogs and tortoises-and I myself worked on human retinas, and that it seems likely that whereas some of these retinas contain vitamin $A_{1}$, others contain vitamin $\mathbf{A}_{2}$. If that is their point, may I put the following questions to them? Is it true that the two types of vitamin A are mutually exclusive? Is it not a fact that both types have been found side by side in the liver ? If they can exist side by side in the liver, why can they not do so in the retina?

(3) Collins and Morton write: "Hartridge also states that the yellow pigment ...". Now if my letter is read again it will be found that it does not contain this statement. What will be found is: "Evidence is to be presented elsewhere for the hypothesis that the yellow pigment . ...".

Medical Research Council

H. Hartridge:

Vision Research Unit,

Institute of Ophthalmology,

Judd Street, London, W.C.1.

${ }^{1}$ Dartnall, H. J. A., Nature, 166, 207 (1950).

"Granit, R., "Sensory Mechanisms of the Retina" (1947).

Hartridge, H., Phil. Trans., B, 232, 519 (1947).

" Parsons, J. H., “An Introduction to the Study of Colour Vision”, 14 (1924).

"Greeff, "Graefe-Saemisch Handb. d. ges. Augenheilkunde", 1, 1, y (1900).

The points raised by Dr. Collins and Prof. Morton and others will be discussed in a forthcoming paper.

Medical Research Council H. J. A. Dartnall

Vision Research Unit,

Institute of Ophthalmology,

Judd Street, London, W.C.1.

\section{TEETH OF FOSSIL PRIMATES AND MODERN APES}

NE of the major obstacles to the development of comparative odontology, especially so far as it bears on the problem of man's origin, has been the lack of objective criteria at the disposal of workers in the field of primate evolution. When in the early 'twenties a single fossil tooth from Nebraska, identified as that of an ape with certain human affinities, Hesperopithecus haroldcookei, was shown later to belong to a peccary, more than one notable anthropologist had reason to hang his head. Since then, the instructed public has been treated to a wide divergence of opinion among other specialists over the human versus ape-like qualitative features of the teeth of Peking man.

In such an impasse, the provision of material which enables less subjective comparisons to be made between the teeth of living anthropomorphous apes and contentious primate fossils is most welcome. Two joint studies by E. H. Ashton and Prof. S. Zuckerman, "Some Quantitative Dental Characteristics of the Chimpanzee, Gorilla and Orang-Outang", and "Some Quantitative Dental Characters of Fossil Anthropoids"*, in turn furnish, according to a rigorously defined technique of measurement, the main absolute and relative dimensions of larger samples of the teeth of modern great apes than have hitherto been available, and then compare statistically the results obtained with the values published by the describers of some extinct primate forms.

Owing to the dubious validity of the sex that has been assigned (all too often with alarming unconcern) to individual, and particularly young, fossil specimens, their dental characters are in each case compared with those of both male and female contem.

* Phit. Trans. Roy. Soc., B, 234: No. 616, "Some Quantitative Dental Characteristics of the Chimpanzee, Gorilla and Orang Outang" (pp. 471-484, 58.); No., 617, "Some Quantitative Dental Ashton and S. Zuckerman. (London: Cambridge University Press, 950.) 
porary anthropomorphs ; and it may be said at once that, in the light of the new data, several previous assertions minimizing the metrical resemblances between the teeth of the fossils and living apes will need modification. No far-reaching claims to have demonstrated more than that which arises of its own accord from the procedure they employ are advanced by the authors; and their reserved attitude stands in sharp contrast to many less-cautious pronouncements, on the basis of dentition, concerning the evolutionary status of the Australopithecines from South Africa and the Proconsul-group from Kenya, to say nothing of the teeth recently found in Java and southern China and attributed to Hominids, and the Piltdown I molars.

Despite the lead given by Simpson and others in the United States, the adoption of statistical methods on the part of palæontologists elsewhere is tardy; and if, as seems probable, one of the effects of the studies described is to induce in them a change of attitude, this can be only for the good. The fulfilment of the authors' promise of a further paper dealing with analogous measurements of teeth of the various races of mankind will be awaited with interest.

\section{HAWAIIAN HONEYCREEPERS}

$T$

$\mathrm{HE}$ Hawaiian Islands are very isolated oceanic islands of volcanic origin. Their great elevation and their position just within the tropical zone athwart the north-east trade winds assure much local variation in climate and rainfall. The climate is tropical and the rainfall in the mountains heavy, producing a luxuriant, though botanically rather undiversified, rain forest wherein the vast majority of the Hawaiian honeycreepers (Drepaniidæ). find their home. These honeycreepers are often cited in general works on evolution as striking examples of adaptive radiation; and, in a recent Bulletin of the American Museum of Natural History (95, No. 4; 1950), Dean Amadon examines existing knowledge in the light of his own observations and assesses the evolutionary significance of these Pacific birds.

The family Drepaniidæ is divisible into two welldefined sub-families; these contain eighteen 'zoogeographical' species, and about twenty-two species in all when geographically representative species are counted separately.

Coefficients of variation for these birds seem to be of the same order of magnitude as for other birds. This is true even of the bill, which has undergone considerable recent adaptive change in several of the genera. As in most birds, the individual variability in bill-length is greater than that in tail-length, and the latter slightly exceeds that in wing-length. No effect on variability of small population size or of specialization could be demonstrated; but the available measurements were not extensive or precise enough to reveal slight differences. Males are larger than females in the Drepaniidæ, sometimes rather markedly so. Sexual difference in bill size is, in some species, relatively greater than that in general size. There is some reason for believing that this is sometimes the result of non-selective positive allometry, especially in the genus Hemignathus. Variations in size and proportions among the races, species, and genera of the family seem to be adaptive; others may or may not be.

Immature drepaniids are rather dull in colour, adult females usually a little brighter, and adult males often brilliant red or orange. In the subfamily, the Drepaniinæ, adult males and females are both brilliant red in several species. Degree of sexual dimorphism in colour occasionally varies abruptly from species to species in a genus or even from race to race. Individual variation in colour is usually slight ; but in one or two forms an orange or yellowish tone may be present or absent. Geographical variation in colour, while occasionally striking, is no more so than in other insular song birds. Red plumage is most frequent in the less specialized members of both sub-families, suggesting that it was characteristic of the earliest drepaniids. In the Drepaniinæ a trend towards black plumage culminates in the entirely black Drepanis funerea.

The Hawaiian honeycreepers are notable for the adaptive radiation which permits them to utilize a variety of foods : nectar, insects (secured in many ways), fruits and seeds. In the Drepaniinæ, four of the five genera are primarily adapted to feeding upon nectar and small insects from flowers. The fifth genus, Ciridops, was evidently frugivorous (its only species became extinct very quickly). Some of the species of the other sub-family are adapted for digging insects from wood; others have very heavy, finch-like bills suitable for crushing seeds and fruit.

The song and call notes of the two sub-families of the Drepaniidæ are quite unlike. Most of the species nest during the spring months and build an open nest of rootlets, moss and similar material. It is placed among the twigs of bushes or trees at widely varying elevations. The eggs vary from two to four in number and are spotted. Apparently only one brood is raised, though more information is needed on this point. All the Hawaiian honeycreepers fly well; but there is slight evidence of incipient reduction of the wing in the two forms native to the little atoll of Laysan.

The Drepaniidæ have a number of known parasites and are subject to various diseases, including bumblefoot, or bird pox, and probably avian malaria. Some or all of these diseases were brought in by introduced birds and may well be the most important factor in the decline and extinction of many of these birds. Other factors adverse to the endemic avifauna are destruction of the forest for agriculture or by livestock, competition with introduced birds, and predation by such introduced mammals as the mongoose, cat and three species of rats.

The small size of many of the insular populations probably tends to limit genetic variability and capacity for adaptive response to changing conditions. With the arrival of the Hawaiians and later of white men on the islands, the environment deteriorated, and widespread extinction of the more vulnerable components of the avifauna quickly ensued.

The supposed phylogeny of the genera of the Drepaniidæe shows that the most primitive genus in each sub-family contains small, arboreal forms with moderately decurved bills and tubular tongues. They feed chiefly on nectar and insects. All the more specialized insect-, nectar-, fruit- and seed-eating genera have evolved from such forms. Some species that no longer eat nectar still have a tubular, nectarsucking tongue like that of the more generalized drepaniids. To suggest derivation of the family from finches or heavy-billed tanagers runs counter to this evidence and to some anatomical characters.

In the Drepaniidæ, as in other birds, the development of species involves gradual differentiation of geographically isolated populations. The isolation 